\title{
Zakres podmiotowy stosunku pracy z mianowania. Refleksje de lege lata i de lege ferenda
}

\author{
The employment relationship on the basis of appointment. \\ De lege lata and de lege ferenda remarks \\ Субъектный состав трудовых отношений, возникающих в результате назначения. \\ Рассуждения de lege lata и de lege ferenda \\ PAULINA MATYJAS-ŁYSAKOWSKA \\ Dr, Uniwersytet Jana Kochanowskiego w Kielcach \\ e-mail: pmatyjas@ujk.edu.pl, https://orcid.org/0000-0002-8734-8338 \\ MAŁGORZATA MĘDRALA \\ Dr, Uniwersytet Ekonomiczny w Krakowie \\ e-mail: medralam@uek.krakow.pl, https://orcid.org/0000-0002-0068-2975
}

\begin{abstract}
Streszczenie: Na łamach niniejszego artykułu Autorki poruszają problematykę zakresu podmiotowego stosunku pracy z mianowania. Zwracają uwagę na zauważalne na gruncie najnowszych regulacji prawa pracy i prawa urzędniczego zjawiska eliminowania mianowania jako podstawy zatrudnienia w niektórych zawodach czy wobec określonych grup pracowników, wprowadzania równoległego względem mianowania zatrudnienia kontraktowego, jak również wprowadzania do zatrudnienia kontraktowego elementów charakterystycznych dla stosunku pracy z mianowania. Celem rozważań jest próba uchwycenia pewnych cech generalnych, które byłyby wyznacznikami zatrudnienia dla określonych grup pracowników w oparciu o tę podstawę nawiązania stosunku pracy.
\end{abstract}

Słowa kluczowe: mianowanie, pragmatyki pracownicze, pracownik, pracodawca, prawo urzędnicze

Summary: On the pages of this article the Authors raise the issue of the subjective scope of an employment relationship on the basis of an appointment. They pay attention to the noticeable phenomenon of an appointment's elimination at the latest regulations of labor law and clerical law as the basis of employment in some professions and some groups of employers, implementation of an appointment in parallel with an employment contract, as well as the implementation of some appointment's elements to an employment contract. The goal of considerations is the attempt to capture some general features which should be determinants of employment for some groups of employees on the basis of an appointment.

Key words: appointment, employee's pragmatics, employee, employer, clerical law

Резюме: В статье авторы обсуждают вопрос о субъективном составе трудовых отношений, возникающих в результате назначения. Они обращают внимание на заметные на основании новейших норм трудового права и законодательства о государственных служащих явления, когда в некоторых профессиях или в отношении определенных групп работников отменяется трудоустройство, возникающее в результате назначения, параллельно с приемом на работу по назначению вводится контрактная форма трудового договора, и, в свою очередь, в контрактные трудовые отношения вносятся элементы, характерные для трудовых отношений, возникающих в результате назначения. Цель настоящей статьи - попытка охарактеризовать отдельные общие черты, которые будут определяющими для конкретных групп работников в рамках данного основания заключения трудовых отношений.

Ключевые слова: назначение, прагматика трудоустройства, работник, работодатель, законодательство о государственных служащих 


\section{Wstęp}

Dostrzegamy kilka zjawisk związanych z prawną regulacją stosunków pracy na podstawie mianowania w pragmatykach pracowniczych. Pierwsze zjawisko to eliminowanie mianowania jako podstawy zatrudnienia w niektórych zawodach czy wobec określonych grup pracowników, drugie to wprowadzanie równoległego względem mianowania zatrudnienia kontraktowego. Spotkać można także regulacje polegające na wprowadzeniu do umownego stosunku pracy (a co ciekawe - również do stosunku pracy na podstawie powołania) elementów charakterystycznych dla stosunku pracy z mianowania.

Zaobserwowane tendencje związane z prawną regulacją stosunku pracy z mianowania stały się dla nas przyczyną do podjęcia rozważań na temat zakresu podmiotowego stosunku pracy z mianowania, a ten artykuł jest publikacją otwierającą rozważania na ten temat. Aktualnie art. 76 Kodeksu pracy (dalej: K.p.) nie określa żadnych kryteriów, od których zależy stosowanie mianowania jako podstawy nawiązania stosunku pracy, ustawodawca ma w tym zakresie dość dużą swobodę. Jest to źródłem braku spójnej koncepcji stosunku pracy z mianowania. Poszukiwanie uzasadnienia dla stosowania mianowania wobec konkretnych grup pracowników rozpoczynamy niniejszą publikacją, której celem jest określenie zakresu podmiotowego stosunku pracy $\mathrm{z}$ mianowania $\mathrm{w}$ wybranych pragmatykach pracowniczych i wskazanie uzasadnienia dla stosowania nominacyjnego stosunku pracy. Rozważania te są wstępem do dalszych badań w tym zakresie. W opracowaniu posłużyłyśmy się tradycyjną dla nauk prawnych metodą dogmatyczną, polegającą na analizie tekstów prawnych, oraz metodą teoretycznoprawną, polegającą na analizie poszczególnych instytucji prawnych w oparciu o doktrynę.

Pragmatyki pracownicze wprowadzają zawodową dyferencjację stosunków pracy. Ich rolą jest dostosowanie określonych rozwiązań prawnych do specyfiki określonego rodzaju pracy, zawodu, branży ${ }^{1}$. Tłumaczy to mocne zróżnicowanie zakresu podmiotowego stosunku pracy z mianowania.

W aktualnych regulacjach mianowanie pracownicze występuje w kilku sferach, m.in. w administracji publicznej, w kontroli państwowej, w wymiarze sprawiedliwości oraz w szkolnictwie i nauce. Pomiędzy pracownikami zatrudnionymi w tych obszarach występują różnice w zakresie rodzaju wykonywanej przez nich pracy, zakresu obowiązków, stopnia podporządkowania, a także treści aktu mianowania. Na

B. Wagner, Stosunek pracy i jego treść, w: Prawo pracy RP w obliczu przemian, red. M. Matey-Tyrowicz, T. Zieliński, Warszawa 2006, s. 156-157; K.W. Baran, Zarys systemu prawa pracy, t. 1. Część ogólna prawa pracy, red. K.W. Baran, Warszawa 2010, s. 375; Z. Sypniewski, Nawiązanie i zmiany stosunku pracy na podstawie mianowania, Warszawa-Poznań, 1976, s. 9. 
potrzeby niniejszego artykułu wybrałyśmy pięć ustaw, które reprezentują wskazane obszary występowania mianowania pracowniczego. Są to:

1) ustawa $\mathrm{z}$ dnia 21 listopada 2008 r. o służbie cywilnej ${ }^{2}$ w zakresie zatrudniania urzędników,

2) ustawa z dnia 23 grudnia 1994 r. o Najwyższej Izbie Kontroli ${ }^{3}$ w zakresie zatrudniania kontrolerów NIK,

3) ustawa z dnia 13 kwietnia 2007 r. o Państwowej Inspekcji Pracy ${ }^{4}$ w zakresie zatrudnienia kontrolerów PIP,

4) ustawa o ustroju sądów powszechnych z dnia 27 lipca 2001 r. ${ }^{5}$ w zakresie zatrudniania sędziów,

5) ustawa - Karta Nauczyciela z dnia 26 stycznia 1982 r. ${ }^{6}$ w zakresie zatrudniania mianowanych i dyplomowanych nauczycieli.

\section{Mianowanie pracownicze $w$ administracji publicznej}

Historycznie mianowanie w różnych okresach funkcjonowania służby cywilnej w Polsce występowało lub nie na poziomie stanowisk urzędniczych w służbie cywilnej. Konkurowały ze sobą dwa modele obsadzania stanowisk w służbie cywilnej: tzw. model pozycyjny i tzw. model kariery. W literaturze wskazuje się, iż cechą charakterystyczną modelu kariery jest przede wszystkim stopniowy, szczeblowy rozwój kariery urzędniczej aż do najwyższych, kierowniczych stanowisk ${ }^{7}$. Jest on bardziej neutralny politycznie. Z kolei model pozycyjny zbliżony jest do zatrudnienia kontraktowego w sektorze prywatnym, nie gwarantuje on stabilizacji zatrudnienia jak w modelu kariery, cechuje się większą elastycznością ${ }^{8}$. Stosunki pracy z mianowania pozostają charakterystyczne dla pierwszego ze wskazanych modeli.

Aktualnie obowiązująca ustawa z dnia 21 listopada 2008 r. o służbie cywilnej stanowi, że mianowanie jest podstawą zatrudnienia dla urzędników służby cywilnej (art. 3 pkt 2). Urzędnicy to jedna $\mathrm{z}$ trzech grup pracowników wchodzących

\footnotetext{
2 Tekst jednolity: Dz. U. z 2020 r. poz. 265 (dalej: ustawa o służbie cywilnej).

3 Dz. U. z 2020 r. poz. 1200 (dalej: ustawa o NIK).

4 Dz. U. z 2019 r. poz. 1251 (dalej: ustawa o PiP).

5 Dz. U. z 2020 r. poz. 365.

6 Dz. U. z 2019 r. poz. 2215 (dalej: Karta Nauczyciela).

$7 \quad$ Za: B. Przywora, L. Bielecki, O potrzebie modernizacji polskiej służby cywilnej - w poszukiwaniu modelu po 20 latach reform, Annales Universitatis Mariae Curie-Skłodowska. Sectio G: Ius 2017, t. 64, nr 2, s. 84 .

8 Tamże, s. 85-86.
} 
w skład korpusu służby cywilnej, obok pracowników i osób zatrudnionych na wyższych stanowiskach w służbie cywilnej. Pracownicy są zatrudniani na podstawie umów o pracę, a wyższe stanowiska w służbie cywilnej obsadzane są w drodze powołania (art. 3 ustawy o służbie cywilnej) $)^{9}$, co oznacza odchylenie w stronę modelu pozycyjnego.

W ustawie o służbie cywilnej mianowanie co do zasady skutkuje przekształceniem nawiązanego stosunku pracy z umownego na nominacyjny. Zgodnie z art. 40 pkt 1 i 2 ustawy o służbie cywilnej o uzyskanie mianowania w służbie cywilnej może ubiegać się osoba, która jest pracownikiem służby cywilnej i posiada co najmniej trzyletni staż pracy w służbie cywilnej lub uzyskała zgodę dyrektora generalnego urzędu na przystąpienie do postępowania kwalifikacyjnego przed upływem tego terminu, jednak nie wcześniej niż po upływie dwóch lat od nawiązania stosunku pracy w służbie cywilnej (wyjątkiem są absolwenci Krajowej Szkoły Administracji Publicznej, którzy składają wniosek o mianowanie na podstawie art. 42 ust. 2 ustawy o służbie cywilnej) $)^{10}$.

Właściwe funkcjonowanie służby cywilnej wymaga zapewnienia wysokiej jakości kadr urzędniczych, a im wyższe stanowisko, tym ustawodawca stawia wyższe wymagania kandydatom. Wyboru najlepszych osób dokonuje się w trakcie postępowania kwalifikacyjnego, którego wynikiem jest uzyskanie mianowania. Ustawa wyróżnia dwie grupy kandydatów mogących ubiegać się o mianowanie: pracowników służby cywilnej oraz absolwentów Krajowej Szkoły Administracji Publicznej. Krajowa Szkoła Administracji Publicznej prowadzi postępowanie kwalifikacyjne dla pracowników służby cywilnej (art. 46-47 ustawy o służbie cywilnej). Oznacza to także, że ustawodawca traktuje mianowanie jako rodzaj wyróżnienia pracownika $\mathrm{w}$ ramach naborów wewnętrznych.

Stosowanie mianowania stanowi o szczególnym statusie danego zawodu z punktu widzenia interesów państwa ${ }^{11}$. W przypadku służby cywilnej wynika ono z kilku powodów. Przede wszystkim konstytucyjny cel jej istnienia, czyli wypełnianie zadań państwa ${ }^{12}$, wymaga od osób je realizujących posiadania szczególnych kwalifikacji

9 Szerzej M. Wieczorek, Obsadzanie wyższych stanowisk w służbie cywilnej w stużbie cywilnej, Acta Scientifica Academiae Ostroviensis, Sectio A: Nauki Humanistyczne, Społeczne i Techniczne 2016, nr 8 (2), s. 133.

10 P. Matyjas-Łysakowska, Dopuszczalność zatrudnienia na czas określony w wybranych pragmatykach pracowniczych, w: Innowacje dla bezpiecznego i zintegrowanego rozwoju, t. 2, red. T. Jarocki, Kielce 2016, s. 159 i nast. Na temat skutków mianowania pomimo niespełniania wymogów ustawowych zob. J. Stelina, w: Prawo urzędnicze. Komentarz, red. K.W. Baran, 2014 [baza danych LEX], Komentarz do art. 40 ustawy o służbie cywilnej, teza 7.

11 E. Ura, Prawo urzędnicze, Warszawa 2011, s. 148.

12 Zob. art. 153 Konstytucji RP. 
i przymiotów osobistych. Jest to niezbędne dla zapewnienia właściwego wykonywania władzy publicznej, a tym samym dla tworzenia odpowiedniego wizerunku państwa w oczach jego obywateli. Stanowi to gwarancję legitymizacji władzy publicznej, a tym samym aprobatę i szacunek dla działań podejmowanych przez państwo $^{13}$. Stosowanie prawa, jego wykładnia, subsumpcja i egzekwowanie dyspozycji norm prawnych wymaga od urzędnika służby cywilnej nie tylko legitymowania się cechami o charakterze formalno-prawnym (jak obywatelstwo czy korzystanie z pełni praw publicznych), ale również pewnych predyspozycji charakterologicznych (np. nieposzlakowana opinia ${ }^{14}$ ), zapewniających wiarygodność podejmowanych decyzji, działań czy rozstrzygnięć. Mianowanie urzędników w służbie cywilnej uzasadnione jest przede wszystkim rodzajem pracy polegającej na wykonywaniu zadań publicznych oraz tradycją i powagą urzędu.

Pełna aprobata stosowania mianowania jako podstawy zatrudnienia urzędników służby cywilnej pozostawia niedosyt, albowiem pracę tego samego rodzaju wykonują pracownicy służby cywilnej, będący również członkami korpusu służby cywilnej, ale zatrudnionymi na podstawie umowy o pracę. Uzyskanie mianowania wiąże się z wyższym statusem zawodowym członka korpusu, wyrażającym się zmianą struktury i zasad wynagradzania oraz większą stabilizacją zatrudnienia, nie powoduje natomiast zmiany zajmowanego stanowiska ani rodzaju wykonywanej pracy $^{15}$. Próżno szukać uzasadnienia dla istniejącego rozróżnienia pracowników od urzędników służby cywilnej w zakresie rodzaju wykonywanej pracy. Na takie zróżnicowanie nie pozwalają także zakreślone przez ustawodawcę kryteria w zakresie ubiegania się przez pracownika służby cywilnej o mianowanie ${ }^{16}$. Takie samo uzasadnienie dla stosowania mianowania wobec urzędników służby cywilnej mogłoby odnosić się do pracowników służby cywilnej. Z tego powodu wydaje się, że mianowanie jako podstawa zatrudnienia służąca wyróżnieniu urzędników służby cywilnej mogłoby mieć zastosowanie także do pracowników służby cywilnej, pozytywnie wpływając na kształtowanie się etosu zawodu urzędnika. Zauważyć przy tym należy, iż systematycznie spada zainteresowanie pracą w służbie cywilnej.

13 Por. M. Kosewski, Etos pracowniczy w urzędach państwowych i samorządowych, Służba Cywilna 2003/2004, nr 7, s. 67 i nast.; J. Arcimowicz, Wzór urzędnika w ustroju demokratycznym, Służba Cywilna 2005, nr 12, s. 35 i nast., A.M. Liwo, Wpływ sprawności działania administracji publicznej na realizację określonych zadań w ujęciu regionalnym i jej konsekwencje w zakresie odpowiedzialności społecznej, Przegląd Prawa Publicznego 2018, nr 4, s. 95-103.

14 Zob. art. 4 pkt 5 ustawy o służbie cywilnej, szerzej H. Szewczyk, Stosunki pracy w służbie cywilnej, 2010 [baza danych LEX], pkt 3.3.6. Wymóg posiadania nieposzlakowanej opinii.

15 J. Stelina, Komentarz do art. 3 ustawy o służbie cywilnej, w: Prawo urzędnicze. Komentarz, red. K.W. Baran, 2014 [baza danych LEX].

16 Zob. art. 40 ustawy o służbie cywilnej. 
W latach 2013-2015 średnia liczba kandydatów w naborach na stanowiska niebędące wyższymi stanowiskami w urzędach centralnych wynosiła odpowiednio 31, 22, 14 kandydatów na miejsce, podczas gdy w latach 2016-2019 średnia liczba kandydatów na jedno miejsce wynosiła odpowiednio $11,7,7,5^{17}$. Spada również odsetek naborów zakończonych obsadzeniem stanowiska. W 2013 r. stosunek naborów zakończonych obsadzeniem stanowiska pracy do ogółu przeprowadzonych naborów wynosił 76\%, a w 2019 r. 57\% ${ }^{18}$. Rozszerzenie zakresu stosowania mianowania i objęcie nim również pracowników służby cywilnej posłużyłoby umocnieniu statusu prawnego zawodu urzędnika. Mianowanie jako podstawa nawiązania stosunku pracy występuje w przypadku urzędników państwowych od początku funkcjonowania ustawy o pracownikach urzędów państwowych z dnia 16 września 1982 r. $^{19}$ W myśl art. 2 ust. 1 ustawy z dnia 2 grudnia 1994 r. o zmianie ustawy o pracownikach urzędów państwowych ${ }^{20}$ począwszy od dnia 27 stycznia 1995 r. z pracownikami urzędów państwowych, wymienionych w art. 1 ustawy o pracownikach urzędów państwowych, nie nawiązuje się stosunku pracy na podstawie mianowania. Nawiązanie stosunku pracy następuje na podstawie umowy o pracę lub, jeżeli przepisy szczególne tak stanowią, na podstawie powołania.

Reasumując, stosowanie mianowania w sferze publicznej ma swoje uzasadnienie $\mathrm{w}$ rodzaju pracy, randze stanowisk urzędniczych oraz jest zakorzenione $\mathrm{w}$ tradycji historycznej. W odniesieniu do zawodu urzędnika na przestrzeni ostatnich kilkunastu lat stosowanie mianowania uległo ograniczeniu. Mamy na myśli wyłączenie mianowania wobec pracowników samorządowych oraz pracowników urzędów państwowych. Zjawisko to określa się w literaturze jako proces laboryzacji stosunków zatrudnienia pracowników państwowych ${ }^{21}$. Warto zauważyć, że umowne stosunki pracy występujące w prawie urzędniczym uregulowane są powszechnym prawem pracy, czyli Kodeksem pracy, z uwzględnieniem odrębności wynikających z poszczególnych pragmatyk pracowniczych. W kontekście prawa urzędniczego mówi się o zastąpieniu mianowania tzw. umowami o zatrudnienie służbowe ${ }^{22}$. Taka umowa o pracę podlegałaby szczególnej regulacji prawnej, na którą rozciągnięte

17 Sprawozdanie Szefa Służby Cywilnej o stanie służby cywilnej i realizacji zadań tej służby w 2019 roku, Załącznik nr 3, wykres 2, https://bip.kprm.gov.pl/kpr/bip-kancelarii-prezesa/sluzba-cywilna/sprawozdania/ 7468,Sprawozdanie-Szefa-Sluzby-Cywilnej-za-2019-rok.html [dostęp: 9.10.2020 r.].

18 Sprawozdanie Szefa Służby Cywilnej o stanie służby cywilnej i realizacji zadań tej służby w 2019 roku, Załącznik nr 3, wykres 4.

19 Dz. U. z 2020 r. poz. 537.

20 Dz. U. z 1994 r. Nr 136, poz. 704.

21 J. Stelina, Stosunki pracy osób pełniących funkcje organów państwa, Warszawa 2016, s. 114.

22 T. Kuczyński, Umowy o zatrudnienie służbowe, w: Szczególne formy zatrudnienia, red. Z. Kubot, Wroclaw 2000, s. 93 i nast. 
zostałyby niektóre ochronne regulacje prawa pracy ${ }^{23}$. To rozwiązanie łączy w sobie dwa skrajne nurty - pomysł całkowitego odejścia od mianowania i podporządkowanie stosunków pracy urzędników powszechnemu prawu pracy, i drugi pomysł przywrócenia mianowania jako powszechnej formy nawiązania stosunku pracy w prawie urzędniczym. Jako rozwiązanie pośrednie pomysł taki zasługuje na uwagę i rozważenie. Odrębne uregulowanie umowy o zatrudnienie służbowe z pewnością przyczyniłoby się do podniesienia rangi zawodu urzędnika. Drugim ważnym postulatem, który udałoby się wówczas zrealizować, to ujednolicenie modelu zatrudniania urzędnika i porzucenie dychotomii podstaw zatrudnienia urzędników.

\section{Mianowanie pracownicze w Najwyższej Izbie Kontroli oraz Państwowej Inspekcji Pracy}

Zatrudnienie na podstawie mianowania przewiduje ustawa z dnia 23 grudnia $1994 \mathrm{r}$. o Najwyższej Izbie Kontroli. Zgodnie z art. 68 ust. 1-2 ustawy stosunek pracy z kontrolerem nawiązuje się na podstawie mianowania, poprzedzonego umową o pracę na czas nie dłuższy niż 3 lata. Kontrolerów mianuje i rozwiązuje z nimi stosunek pracy Prezes Najwyższej Izby Kontroli. Rozwiązanie stosunku pracy z mianowanymi kontrolerami - członkami Kolegium Najwyższej Izby Kontroli - wymaga zgody Kolegium. Mianowanie jest uzależnione od odbycia aplikacji kontrolerskiej zakończonej złożeniem egzaminu z wynikiem pozytywnym przed komisją egzaminacyjną powołaną przez Prezesa Najwyższej Izby Kontroli. Aplikacja kontrolerska ma na celu teoretyczne i praktyczne przygotowanie kontrolera do wykonywania i nadzorowania czynności kontrolnych.

Zbliżone rozwiązania zawiera ustawa z dnia 13 kwietnia 2007 r. o Państwowej Inspekcji Pracy w stosunku do kontrolerów. Zwrócić należy uwagę, że mianowanie dotyczy tylko osób wykonujących czynności kontrolne (art. 38 ust. 1 pkt 3 i ust. 2 ustawy o PiP). Mianowanie jest uzależnione od odbycia aplikacji inspektorskiej zakończonej złożeniem państwowego egzaminu z wynikiem pozytywnym przed komisją egzaminacyjną powołaną przez Głównego Inspektora Pracy. Główny Inspektor Pracy może, w przypadkach uzasadnionych kwalifikacjami lub praktyką zawodową, mianować pracownika wykonującego czynności kontrolne bez uprzedniego

23 T. Liszcz, Pozaumowne stosunki pracy, w: Prawo pracy RP w obliczu przemian, red. M. Matey-Tyrowicz, T. Zieliński, Warszawa 2006, s. 248; Z. Góral, Stosunki pracy z mianowania z perspektywy 40 lat obowiazywania Kodeksu pracy, Studia Iuridica Lublinensia 2015, t. 24, nr 3, s. 363. 
zawierania umowy o pracę, a także bez zachowania wymogu aplikacji inspektorskiej. Zgodnie $\mathrm{z}$ art. 41 ust. 1 ustawy o PiP stosunek pracy z mianowania powinien być, co do zasady, poprzedzony zatrudnieniem na podstawie umowy o pracę zawartej na czas określony, nie dłuższy niż 3 lata.

W tym miejscu warto wskazać na art. 6 Konwencji nr 81 Międzynarodowej Organizacji Pracy dotyczący inspekcji pracy w przemyśle i handlu, przyjętej w Genewie dnia 11 lipca $1947 \mathrm{r}^{24}$, stanowiący, że personel inspekcji pracy będzie składał się z urzędników publicznych, których status i warunki służby zapewniają stałość zatrudnienia oraz niezależność od wszelkich zmian rządu i od jakichkolwiek niewłaściwych wpływów z zewnątrz. W kontekście Konwencji MOP zatrudnienie na podstawie umów terminowych pracowników kontroli inspekcji pracy budzi w doktrynie uzasadnione wątpliwości ${ }^{25}$. Umowa o pracę zawarta na czas określony, która poprzedza zatrudnienie kontrolera $\mathrm{PiP}$ na podstawie mianowania, nie korzysta ze wzmożonej ochrony trwałości zatrudnienia i przez to nie stanowi gwarancji stabilizacji stosunku pracy ${ }^{26}$. W tym przypadku w naszej ocenie mianowanie na czas określony mogłoby zapewnić stabilizację, o której mowa w Konwencji MOP.

\section{Mianowanie pracownicze nauczycieli}

Szczególna ranga społeczna zawodu nauczyciela uzasadnia utrzymanie wobec nich zatrudnienia na podstawie mianowani ${ }^{27}$. Przesłanki zatrudniania na podstawie mianowania nauczycieli ze stopniem awansu zawodowego nauczyciela mianowanego i dyplomowanego określa art. 10 ust. 5 Karty Nauczyciela. Karta Nauczyciela przewiduje również tzw. mianowanie z mocy prawa w sytuacji przekształcenia umownego stosunku pracy zawartego na czas nieokreślony w stosunek pracy z mianowania w przypadku spełnienia warunków ustawowych (art. 10 ust. 5a Karty

24 Dz. U. z 1997 r. Nr 72, poz. 450 (dalej: Konwencja MOP).

25 K. Antolak-Szymanski, T. Niedziński, w: Ustawa o Państwowej Inspekcji Pracy, 2016 [baza danych Legalis], Komentarz do art. 38; A. Jasińska-Cichoń, w: Ustawa o Państwowej Inspekcji Pracy. Komentarz, 2008 [baza danych LEX], Komentarz do art. 41.

26 Por. wątpliwości w tym zakresie podnoszone przez D. Makowskiego. D. Makowski, Inspekcja Pracy jako instytucja państwowego nadzoru nad przestrzeganiem prawa pracy, Łódź 2017, s. 136-138.

27 D. Dwojewski, Wybrane problemy zatrudniania nauczycieli w szkołach i placówkach publicznych podległych jednostkom samorzadu terytorialnego, Przegląd Prawa Publicznego 2013, nr 7-8, s. 188-209 [baza danych LEX]. 
Nauczyciela $)^{28}$. Przekształcenie podstawy prawnej stosunku pracy potwierdza na piśmie dyrektor szkoły.

Nauczyciel rozpoczyna pracę od zatrudnienia na podstawie umowy o pracę, a wraz z osiągnięciem kolejnych stopni awansu zawodowego uzyskuje mianowanie. Mianowanie jest zwieńczeniem ścieżki zawodowej nauczyciela. Przy czym nauczyciel zatrudniony na podstawie mianowania i zatrudniająca go szkoła mogą pozostawać w stosunku pracy na tej podstawie co do zasady w pełnym wymiarze zajęć (art. 10 ust. 5 pkt 6 Karty Nauczyciela) lub wyjątkowo w niepełnym wymiarze zajęć (art. 22 ust. 2 Karty Nauczyciela). Taki wymóg świadczy o potrzebie związania nauczyciela zatrudnionego na podstawie mianowania ze szkołą, w której pracuje.

Historycznie status prawny nauczycieli mianowanych był regulowany ustawą z dnia 1 lipca 1926 r. o stosunkach służbowych nauczycieli ${ }^{29}$. Konieczność odrębnej regulacji sytuacji prawnej nauczycieli mianowanych wynikała ze szczególnego rodzaju i charakteru ich pracy polegającej na nauczaniu i wychowaniu ${ }^{30}$. Stosunek służbowy nauczycieli mianowanych miał charakter publicznoprawny i mógł być zmieniony, zawieszony lub rozwiązany wyłącznie przy zastosowaniu przepisów prawa publicznego, a w szczególności postanowień pragmatyki (art. 2) ${ }^{31}$. Również ustawa $\mathrm{z}$ dnia 27 kwietnia 1956 r. o prawach i obowiązkach nauczycieli ${ }^{32}$ realizowała zasadę stabilizacji stosunku pracy nauczycieli mianowanych i ich uprzywilejowania względem nauczycieli kontraktowych, w szczególności poprzez enumeratywne określenie przyczyn prowadzących do jego ustania ${ }^{33}$. W kolejnej ustawie z dnia 27 kwietnia 1972 r. - Karta praw i obowiązków nauczyciela ${ }^{34}$ podstawową formę zatrudnienia nauczyciela stanowiło mianowanie. W art. 79 tej ustawy ${ }^{35}$ użyte było wprost sformułowanie, że z nauczycielem i nauczycielem akademickim zawiązuje się stosunek pracy. Tym samym ostatecznie odstąpiono od postrzegania pracy nauczyciela jako służby państwowej ${ }^{36}$. Do dnia wejścia w życie ustawy z dnia 4 maja 1982 r. o szkolnictwie wyższym Karta praw i obowiązków nauczyciela

28 Szerzej: J. Stelina, Mianowanie z mocy prawa, GSP 2005, nr 2, s. 971-984.

29 Dz. U. z 1926 r. Nr 92, poz. 530.

30 Szerzej na temat rozwoju historycznego statusu nauczycieli mianowanych W. Jędrychowska-Jaros, Rozdział I. Kształtowanie się sytuacji prawnej nauczycieli mianowanych, pkt 1.2., w: Stosunek pracy nauczyciela mianowanego, 2011 [baza danych LEX].

31 Tamże.

32 Dz. U. z 1956 r. Nr 12, poz. 63.

33 W. Jędrychowska-Jaros, Rozdział I. Ksztattowanie się..., pkt 2.2.

34 Dz. U. z 1972 r. Nr 16, poz. 114.

35 Dz. U. Nr 16, poz. 114 z późn. zm. (dalej: Karta praw i obowiązków nauczyciela).

36 P. Matyjas-Łysakowska, A teacher's employment by appointment in the context of contemporary labour law challenges, w: New forms of employment. Current Problems and future Challenges, red. J. Wratny, A. Ludera-Ruszel, Wiesbaden 2020, s. 271. 
miała częściowe zastosowanie wobec nauczycieli akademickich państwowych szkół wyższych (art. 1 ust. 1 pkt 2 Karty praw i obowiązków nauczyciela) ${ }^{37}$.

Pomimo ciągłych zmian przepisów zatrudnieniowych nauczycieli mianowanie zostało utrzymane do dnia dzisiejszego. Można więc twierdzić, iż za jego utrzymaniem stoją względy historyczne, tradycja, etos zawodu nauczyciela, jak również rodzaj pracy związany z nauczaniem i wychowywaniem młodego pokolenia.

\section{Mianowanie pracownicze sędziów}

Stosunek pracy na podstawie mianowania jest przewidziany w stosunku do sędziów, choć ustawa posługuje się (pozornie mylącym) pojęciem aktu powołania (art. 65 ustawy o ustroju sądów powszechnych). Stosunek pracy na podstawie mianowania nawiązuje się także $\mathrm{z}$ asesorami sądowymi (art. 106h ustawy - Prawo o ustroju sądów powszechnych).

W nauce prawa wskazuje się na wątpliwości co do charakteru prawnego formy zatrudnienia sędziów i asesoró ${ }^{38}$, a mianowicie, czy mamy do czynienia ze stosunkami służbowymi czy stosunkami pracy. Przeważa jednak stanowisko, że w tych przypadkach chodzi o stosunki pracy, a podstawą zatrudnienia jest mianowanie ${ }^{39}$. Ustawa szczegółowo określa rygory selekcyjne kandydatów na stanowiska sędziego i asesora, kwestie wynagrodzeniowe, immunitetowe, odpowiedzialności dyscyplinarnej, prawa i obowiązki.

Mianowanie jest podstawą zatrudniania sędziów Sądu Najwyższego ${ }^{40}$, aczkolwiek uregulowane w odrębnej ustawie. Również zatrudnienie sędziów i asesorów w sądach administracyjnych uregulowane jest odrębnie ${ }^{41}$. Z kolei zatrudnianie urzędników w Sądzie Najwyższym jest regulowane przepisami ustawy z dnia 16 września 1982 r. o pracownikach urzędów państwowych (art. 1 ust. pkt 3b).

\footnotetext{
37 Tamże, s. 257.

38 Zob. A. Rycak, Regulacje prawne zatrudnienia pracowników sądów jako szczególne prawo pracy, w: Powszechne a szczególne prawo pracy, red. L. Florek, Warszawa 2016, s. 282, 284-286.

39 Szerzej kwestię tę analizuje K. Stefański, Zakres stosunku pracy $z$ mianowania $w$ organach ochrony prawnej, w: System prawa pracy, t. 4. Indywidualne prawo pracy. Pozaumowne stosunki pracy, red. Z. Góral, Warszawa 2017, s. 435-436, wraz z przytaczanym tam orzecznictwem i literaturą.

40 Art. 29 i nast. ustawy z dnia 8 grudnia 2017 r. o Sądzie Najwyższym, Dz. U. z 2019 r. poz. 825.

41 Art. 5-8 ustawy - Prawo o ustroju sądów administracyjnych z dnia 25 lipca 2002 r., Dz. U. z 2019 r. poz. 2167.
} 
Z tego powodu w literaturze zwraca się uwagę na brak w polskim ustawodawstwie jednolitej pragmatyki sądowej, jednocześnie akceptując potrzebę odrębnej regulacji zatrudnienia tej grupy pracowników ${ }^{42}$.

Stosowanie mianowania jako podstawy zatrudnienia w przypadku sędziów uzasadniają względy tradycji, powaga urzędu związanego z pełnieniem części władzy publicznej oraz liczne cechy tego stosunku pracy, które świadczą o służbowo-pracowniczym charakterze mianowania sędziów i asesorów, czyli np. akt powierzenia stanowiska pracy. Szczególnie ważne jest, by grupa sędziów i asesorów sprawujących władzę publiczną korzystała ze stabilności zatrudnienia i nie była poddawana wpływom politycznym.

\section{Powołanie pracownicze o cechach mianowania pracowniczego}

Kolejną ciekawą cechą obecnych pozaumownych stosunków pracy z perspektywy modelu stosunku pracy z mianowania jest występowanie w niektórych pragmatykach pracowniczych stosunków pracy z powołania, które w istocie wykazują cechy stosunku pracy z mianowania. Przykładem jest stosunek pracy dyrektora instytucji kultury (art. 15-16 ustawy z dnia 25 października 1991 r. o organizowaniu i prowadzeniu działalności kulturalnej ${ }^{43}$ ). Dyrektor instytucji kultury jest zatrudniany na podstawie powołania w rozumieniu art. $68 \mathrm{~K} . p .{ }^{44}$. Może to być przy tym wyłącznie powołanie na czas określony ${ }^{45}$. Odmiennością w stosunku do ogólnej regulacji K.p. dotyczącej możliwości odwołania w każdym czasie pracownika zatrudnionego na podstawie powołania (art. $70 \$ 1$ K.p.) jest to, iż dyrektor instytucji kultury może być odwołany ze stanowiska przed upływem czasu powołania tylko w przypadkach wskazanych wyczerpująco przez ustawodawcę (art. 15 ust. 6 ustawy o organizowaniu i prowadzeniu działalności kulturalnej). Stanowi to ewenement wśród stosun-

\footnotetext{
42 A. Rycak, Regulacje prawne..., s. 297-298, wraz z przywoływaną tam literaturą.

43 Ustawa z dnia 25 października 1991 r. o organizowaniu i prowadzeniu działalności kulturalnej, Dz. U. 2020 poz. 194 (dalej: ustawa o organizowaniu i prowadzeniu działalności kulturalnej).

44 Zob. postanowienie SN z 13 września 2005 r., I PK 104/05, Legalis nr 309607; uchwała SN z 11 stycznia 2005 r., I PZP 11/04, Legalis nr 66651; J. Stelina, Zakres podmiotowy stosunków pracy z powołania. Nawiązanie stosunku pracy z dyrektorem instytucji kultury. Glosa do uchwały SN z 11 stycznia 2005 r., I PZP 11/04, Gdańskie Studia Prawnicze - Przegląd Orzecznictwa 2005, nr 4, s. 117-123.

45 Dlatego też przepis ten należy traktować jako lex specialis do art. $68 \$ 1^{1} \mathrm{~K}$.p., zgodnie którym stosunek pracy na podstawie powołania nawiązuje się na czas nieokreślony, a jeżeli na podstawie przepisów szczególnych pracownik został powołany na czas określony, stosunek pracy nawiązuje się na okres objęty powołaniem.
} 
ków pracy nawiązanych na podstawie powołania, albowiem ma na celu zapewnienie dość istotnej stabilności i pewności zatrudnienia w okresie powołania. Konstrukcja ta zbliżona jest bardziej do przesłanek rozwiązania stosunku pracy przy mianowaniu niż do tradycyjnej konstrukcji powołania ${ }^{46}$. Zapewnia sporą stabilność zatrudnienia w okresie nawiązanego stosunku pracy i dlatego bardziej przypomina konstrukcyjnie mianowanie na czas określony. Możliwość odwołania dyrektora instytucji kultury jedynie w przypadku zaistnienia ściśle wskazanych przesłanek wskazanych w cytowanym przepisie przeczy istocie powołania.

\section{Przyszłość stosunku pracy z mianowania}

Przeprowadzona analiza pokazuje, iż brak jest nie tylko w K.p., ale także w pragmatykach pracowniczych, kryteriów uzasadniających stosowanie mianowania jako podstawy zatrudnienia wobec konkretnych grup pracowników.

Konieczność zróżnicowania rozwiązań normatywnych, objętych analizą grup zawodowych wynika $\mathrm{z}$ potrzeby ochrony szeroko pojętego interesu publicznego bądź wyróżnienia określonej grupy zawodowej ze względu na wieloletnią tradycję i etos zawodu. Chociaż formalnie o mianowaniu nie decyduje rodzaj wykonywanej pracy, to $\mathrm{w}$ każdym analizowanym przypadku rodzaj pracy wykonywanej przez pracowników mianowanych wykazuje - bardziej lub mniej wyeksponowane - cechy służby na rzecz interesu publicznego. Zatrudnienie na podstawie mianowania urzędników służby cywilnej, kontrolerów NIK i PiP, sędziów i asesorów sądowych jest związane z wykonywaniem zadań o szczególnym znaczeniu dla interesów państwa i społeczeństwa. Szczególny status tych pracowników związany jest $\mathrm{z}$ tym, że osoby piastujące te stanowiska powinny być bezstronne i niezależne, neutralne politycznie, odporne na zmiany polityczne. Praca, która nosi znamiona służby państwowej i wymaga szczególnego zaangażowania oraz dyspozycyjności, powinna wyróżniać się odpowiednio wysokim statusem prawnym i stosowną pozycją społeczną.

Naszym zdaniem mianowanie jako podstawa zatrudnienia powinno funkcjonować tam, gdzie występuje związek wykonywanej pracy z funkcjami państwa; gdzie wykonywanie pracy wiąże się z uczestniczeniem w wykonywaniu zadań państwa (w tym także wśród pracowników administracji samorządowej i pracowników

Zob. M. Mędrala, w: A. Gawrońska-Baran i in., Vademecum dyrektora instytucji kultury, Warszawa 2019, s. 107. 
urzędów państwowych). Przeprowadzona analiza pokazała, iż w większości przypadków (za wyjątkiem sędziów i asesorów sądowych) te same obowiązki równolegle wykonują pracownicy umowni (pracownicy służby cywilnej czy kontrolerzy PiP zanim uzyskają akt mianowania, a także nauczyciele zatrudnieni w oświacie). W obecnym ustawodawstwie mamy do czynienia ze zjawiskiem traktowania mianowania jako kolejnego stopnia w karierze zawodowej, które znacząco różni od umowy o pracę tylko zwiększona trwałość zatrudnienia. Słusznie wskazywanym celem stabilności zatrudnienia w sferze publicznej jest zapewnienie obywatelom prawa do dobrej administracji ${ }^{47}$. Stabilność zatrudnienia stanowi istotną gwarancję neutralności i obiektywizmu, a takie wartości są cenne dla każdego pracownika zatrudnionego w sferze publicznej.

Opowiadamy się więc nie tylko za utrzymaniem mianowania tam, gdzie ono $\mathrm{w}$ tej chwili stanowi podstawę zatrudnienia, ale za wzmocnieniem pozycji prawnej pracowników służby cywilnej i administracji samorządowej poprzez rozszerzenie stosowania mianowania także na te grupy. Naszym zdaniem przemawia za tym rodzaj wykonywanej pracy. Opowiadamy się za stworzeniem gwarancji stabilności zatrudnienia dla kontrolerów NIK i PiP poprzez rozszerzenie stosowania mianowania na wszystkie osoby pełniące funkcje kontrolne w tych instytucjach, a nie tylko jako stopnia awansu zawodowego. Postulatem de lege ferenda jest propozycja wprowadzenia instytucji mianowania na czas określony, poprzedzający mianowanie bezterminowe. Ten określony czas mianowania służyłby przygotowaniu do pracy i sprawdzeniu gotowości do wykonywania zadań służbowych, ale jednocześnie dawałby poczucie uprzywilejowania i większą gwarancję zaangażowania pracownika, podkreślając rangę wykonywanego przez niego zawodu.

Mianowanie należałoby utrzymać również w publicznych szkołach, w państwowych szkołach wyższych, w Polskiej Akademii Nauk ${ }^{48}$ - tam gdzie zadania pracowników polegają na dbaniu o rozwój oświaty i nauki. Uzasadnione wątpliwości budzi naszym zdaniem wyeliminowanie przez ustawodawcę mianowania z ustawy z dnia 20 lipca 2018 r. - Prawo o szkolnictwie wyższym i nauce ${ }^{49}$. Zgodnie z art. 117 ust. 1 ustawy - Prawo o szkolnictwie wyższym i nauce umowa o pracę jest jedyną formą nawiązania stosunku pracy z pracownikiem uczelni. Według art. 248 ust. 1 ustawy zawierającej przepisy wprowadzające ustawę - Prawo

47 M. Wieczorek, Obsadzanie wyższych stanowisk w służbie cywilnej, Acta Scientifica Academiae Ostroviensis, Sectio A: Nauki Humanistyczne, Społeczne i Techniczne 2016, nr 8 (2), s. 121-122.

48 Także na niższych stanowiskach niż profesorskich.

49 Dz. U. z 2020 r. poz. 85 (dalej: ustawa - Prawo o szkolnictwie wyższym i nauce). Ustawa obecnie nie przewiduje zatrudnienia na podstawie mianowania. 
o szkolnictwie wyższym i nauce ${ }^{50}$ pracownicy uczelni zatrudnieni w uczelniach na podstawie mianowania w dniu wejścia w życie ustawy - Prawo o szkolnictwie wyższym i nauce pozostają zatrudnieni w tej samej formie i na ten sam okres ${ }^{51}$. Nowa ustawa zerwała ostatecznie $\mathrm{z}$ tradycją zatrudniania na podstawie mianowania w szkolnictwie wyższym, nie przewidując nawet możliwości uhonorowania wysiłku naukowego zwieńczonego uzyskaniem tytułu naukowego profesora zatrudnieniem na podstawie mianowania ${ }^{52}$. Stosunek pracy z mianowania został natomiast utrzymany w ustawie z dnia 30 kwietnia 2010 r. o Polskiej Akademii Nauk na stanowiskach profesora lub profesora instytutu ${ }^{53}$. W tym przypadku ustawodawca traktuje więc nadal tę podstawę zatrudnienia jako swoiste zwieńczenie kariery naukowej w instytutach PAN.

Model zatrudniania na podstawie mianowania w obszarach oświaty, szkolnictwa wyższego i nauki wymaga oczywiście bardziej szczegółowej analizy, ale daje się zauważyć, że w obecnym kształcie jest bardzo niespójny. Prezentujemy pogląd, iż w K.p. powinny znaleźć się co najmniej ogólne regulacje dotyczące zasad zatrudniania na podstawie mianowania m.in. z zakresu występowania mianowania, formy, trybu oraz treści aktu mianowania ${ }^{54}$ tak, aby przepisy ogólne dotyczące mianowania były jednolite. W pozostałym zakresie status prawny pracowników mianowanych, ze względu na liczne odrębności i specyfikę, powinien być poddany szczególnej regulacji w pragmatykach pracowniczych.

Stosunek pracy z mianowania nieodłącznie związany jest ze sferami życia, gdzie występują elementy o charakterze publicznym. Popieramy pojawiający się w literaturze postulat związany z potrzebą stworzenia wspólnych, spójnych i w miarę jednolitych przepisów dla grupy pragmatyk wyróżniających się wspólnymi cechami, w szczególności dla urzędników i sędziów ${ }^{55}$.

Różnorodność podstaw zatrudnienia jest cennym dorobkiem prawa pracy. Uważamy, że korzystanie z poszczególnych form zatrudnienia powinno odbywać

50 Ustawa z dnia 3 lipca 2018 r. - Przepisy wprowadzające ustawę - Prawo o szkolnictwie wyższym i nauce, Dz.U. z 2018 r. poz. 1669.

51 Szerzej na temat dylematów związanych ze stosowaniem wobec pracowników mianowanych starych przepisów o mianowaniu czy o umowie o pracę zob. E. Prokop-Perzyńska, M. Wieczorek, Zarys ewolucji mianowania jako podstawy zatrudniania nauczycieli akademickich, Annales Universitatis Mariae Curie-Skłodowska, Sectio G: Ius, 2020, t. 67, nr 2, s. 149-159.

52 T. Kuczyński, w: Akademickie prawo zatrudnienia. Komentarz, red. K.W. Baran, 2020 [baza danych LEX], Komentarz do art. 117.

53 Zob. art. 91 ust. 1 ustawy o Polskiej Akademii Nauk z dnia 30 kwietnia 2010 r., Dz. U. z 2019 r. poz. 1183.

54 Por. T. Liszcz, Glosa do uchwaty SN z dnia 3 kwietnia 1997 r., III ZP 14/97, OSP 1998, nr 4, s. 73.

55 P. Nowik, Jednolita pragmatyka urzędnicza a powszechne prawo pracy, w: Powszechne a szczególne prawo pracy, red. L. Florek, Warszawa 2016, s. 81 i wskazana tam literatura. 
się z poszanowaniem im tylko właściwych cech. Niepokojące w naszej ocenie jest przenikanie do umownego stosunku pracy cech właściwych stosunkom pracy z mianowania (vide odpowiedzialność dyscyplinarna pracowników służby cywilnej, osób zajmujących wyższe stanowiska w służbie cywilnej ${ }^{56}$, nauczycieli ${ }^{57}$ i nauczycieli akademickich ${ }^{58}$ ), a także nadawanie cech charakterystycznych dla stosunku pracy $\mathrm{z}$ mianowania stosunkom pracy zawieranym $\mathrm{w}$ oparciu o powołanie (vide przykład zatrudnienia dyrektora instytucji kultury). Powoduje to, że zanika czytelny rozdział pomiędzy umową o pracę a mianowaniem.

Aktualnie mianowanie, za którym idzie wzmożona ochrona trwałości zatrudnienia, nie wpisuje się w politykę elastycznego prawa pracy. Obserwując tendencję do rezygnacji z mianowania jako podstawy zatrudnienia, można się zastanowić, czy ustawodawca nie zmierza do tego, aby zrezygnować w ogóle z tej formy zatrudnienia na rzecz umownego stosunku pracy, zawierającego tylko wybrane cechy stosunku pracy z mianowania, tak jak to uczynił w przypadku nauczycieli akademickich w ustawie z dnia 20 lipca 2018 r. - Prawo o szkolnictwie wyższym i nauce, a wcześniej wobec pracowników samorządowych ustawą z dnia 21 listopada 2008 r. o pracownikach samorządowych.

Mianowanie jest silnie zakorzenione w prawie pracy i w naszej ocenie nie należy z tej podstawy zatrudnienia rezygnować. Jest także elementem, który niejednokrotnie stanowił pewną dodatkową zachętę do kontynuowania kariery w grupach zawodowych nim objętych. Wyeliminowanie tej podstawy nawiązania stosunku pracy, w kontekście stosunkowo niższych zarobków kadry pracowników mianowanych w relacji do sektora prywatnego, może skutkować brakiem zainteresowania i motywacji do kontynuacji kariery w określonych zawodach przez osoby o obiecującym potencjale w tym kierunku. A w konsekwencji może - naszym zdaniem skutkować generalnym pogorszeniem jakości kadry pracowniczej na stanowiskach w sektorze publicznym.

\section{Bibliografia}

Antolak-Szymański K., Ustawa o Państwowej Inspekcji Pracy, 2016 [baza danych Legalis], Komentarz do art. 38.

Arcimowicz J., Wzór urzędnika w ustroju demokratycznym, Służba Cywilna 2005, nr 12.

56 Art. 113 ust. 1 ustawy o służbie cywilnej oraz art. 114 ust. 2 ustawy o służbie cywilnej.

57 Art. 75 ust. 1 Karty Nauczyciela.

58 art. 275 ust. 1 ustawy - Prawo o szkolnictwie wyższym i nauce. 
Baran K.W., Zarys systemu prawa pracy, t. 1. Część ogólna prawa pracy, red. K.W. Baran, Warszawa 2010.

Dwojewski D., Wybrane problemy zatrudniania nauczycieli w szkołach i placówkach publicznych podległych jednostkom samorządu terytorialnego, Przegląd Prawa Publicznego 2013, nr 7-8 [baza danych LEX].

Góral Z., Stosunki pracy z mianowania z perspektywy 40 lat obowiązywania Kodeksu pracy, Studia Iuridica Lublinensia 2015, t. 24, nr 3.

Jasińska-Cichoń A., Ustawa o Państwowej Inspekcji Pracy. Komentarz, 2008 [baza danych LEX], Komentarz do art. 41.

Jędrychowska-Jaros W., Stosunek pracy nauczyciela mianowanego, 2011 [baza danych LEX]. Korus P., w: Kodeks pracy, red. A. Sobczyk, 2018 [baza danych Legalis], Komentarz do art. 76.

Kosewski M., Etos pracowniczy w urzędach państwowych i samorządowych, Służba Cywilna 2003/2004, nr 7.

Kuczyński T., Umowy o zatrudnienie służbowe, w: Szczególne formy zatrudnienia, red. Z. Kubot, Wrocław 2000.

Kuczyński T., w: Akademickie prawo zatrudnienia. Komentarz, red. K.W. Baran, 2020 [baza danych LEX], Komentarz do art. 117.

Liszcz T., Glosa do uchwały SN z dnia 3 kwietnia 1997 r., III ZP 14/97, OSP 1998, nr 4.

Liszcz T., Pozaumowne stosunki pracy, w: Prawo pracy RP w obliczu przemian, red. M. Matey-Tyrowicz, T. Zieliński, Warszawa 2006.

Liwo A.M., Wpływ sprawności działania administracji publicznej na realizację określonych zadań w ujęciu regionalnym i jej konsekwencje w zakresie odpowiedzialności społecznej, Przegląd Prawa Publicznego 2018, nr 4.

Makowski D., Inspekcja Pracy jako instytucja państwowego nadzoru nad przestrzeganiem prawa pracy, Łódź 2017.

Matyjas-Łysakowska P., A teacher's employment by appointment in the context of contemporary labour law challenges, w: New forms of employment. Current Problems and future Challenges, red. J. Wratny, A. Ludera-Ruszel, Wiesbaden, 2020.

Matyjas-Łysakowska P., Dopuszczalność zatrudnienia na czas określony w wybranych pragmatykach pracowniczych, w: Innowacje dla bezpiecznego i zintegrowanego rozwoju, t. 2, red. T. Jarocki, Kielce 2016.

Mędrala M., w: A. Gawrońska-Baran i in., Vademecum dyrektora instytucji kultury, Warszawa 2019.

Nowik P., Jednolita pragmatyka urzędnicze a powszechne prawo pracy, w: Powszechne a szczególne prawo pracy, red. L. Florek, Warszawa 2016.

Prokop-Perzyńska E., Wieczorek M., Zarys ewolucji mianowania jako podstawy zatrudniania nauczycieli akademickich, Annales Universitatis Mariae Curie-Skłodowska, Sectio G: Ius 2020, t. 67, nr 2.

Przywora B., Bielecki L., O potrzebie modernizacji polskiej służby cywilnej - w poszukiwaniu modelu po 20 latach reform, Annales Universitatis Mariae Curie-Skłodowska, Sectio G: Ius 2017, t. 64, nr 2.

Rycak A., Regulacje prawne zatrudnienia pracowników sądów jako szczególne prawo pracy, w: Powszechne a szczególne prawo pracy, red. L. Florek, Warszawa 2016.

Sprawozdanie Szefa Służby Cywilnej o stanie służby cywilnej i realizacji zadań tej służby w 2019 roku, Załącznik nr 3, wykres 2, wykres 4, https://bip.kprm.gov.pl/kpr/ 
bip-kancelarii-prezesa/sluzba-cywilna/sprawozdania/7468,Sprawozdanie-Szefa-Sluzby-Cywilnej-za-2019-rok.html [dostęp: 9.10.2020 r.].

Stefański K., Zakres stosunku pracy z mianowania w organach ochrony prawnej, w: System prawa pracy, t. 4. Indywidualne prawo pracy. Pozaumowne stosunki pracy, red. Z. Góral, Warszawa 2017.

Stelina J., Mianowanie z mocy prawa, Gdańskie Studia Prawnicze 2005, nr 2.

Stelina J., Zakres podmiotowy stosunków pracy z powołania. Nawiązanie stosunku pracy $z d y$ rektorem instytucji kultury. Glosa do uchwały SN z 11 stycznia 2005 r., I PZP 11/04, Gdańskie Studia Prawnicze - Przegląd Orzecznictwa 2005, nr 4.

Stelina J., Komentarz do art. 3 ustawy o służbie cywilnej, w: Prawo urzędnicze. Komentarz, red. K.W. Baran, 2014 [baza danych LEX].

Stelina J., Stosunki pracy osób petniących funkcje organów państwa, Warszawa 2016.

Sypniewski Z., Nawiazanie i zmiany stosunku pracy na podstawie mianowania, WarszawaPoznań 1976.

Szewczyk H., Stosunki pracy w służbie cywilnej, 2010 [baza danych LEX].

Ura E., Prawo urzędnicze, Warszawa 2011.

Wagner A., Stosunek pracy i jego treść, w: Prawo pracy RP w obliczu przemian, red. M. Matey-Tyrowicz, T. Zieliński, Warszawa 2006.

Wieczorek M., Obsadzanie wyższych stanowisk w służbie cywilnej, Acta Scientifica Academiae Ostroviensis, Sectio A: Nauki Humanistyczne, Społeczne i Techniczne 2016, nr 8 (2). 
